$7^{\circ}$ Simposio Internacional de Investigación Multidisciplinaria / Ciencia y Tecnología 7th Internationalm Symposium on Multidisciplinary Research / Sciences and Technology

\title{
CT-09 Efecto de la nanotecnología en la capa activa de dispositi- vos fotovoltaicos utilizando derivados de porfirinas
}

Effect of nanotechnology on the active layer of photovoltaic devices using porphyrin derivatives

\author{
Susana Arrechea ${ }^{1 *}$, Fernando Langa ${ }^{2}$, Pilar de la Cruz ${ }^{2}$
}

${ }^{1}$ Escuela de Ingeniería Química, Facultad de Ingeniería, Universidad de San Carlos de Guatemala e ${ }^{2}$ Instituto de Nanociencia, Nanotecnología y Materiales Moleculares, Universidad de Castilla-La Mancha, España

*Autor al que se dirige la correspondencia: arrecheausac@gmail.com

\section{Resumen}

a nueva generación de fotovoltaicas tiene un enfoque alternativo y complementario para la explotación de la
energía solar; con bajo coste de fabricación, flexibilidad, transparencia y peso ligero. Las células solares más
prometedoras por su notable progreso son las células solares orgánicas (OSC), células solares sensibilizadas por
colorante (híbridas) y células solares de perovskita. Las porfirinas, que son análogos sintéticos de las clorofilas
naturales, son de especial interés, debido a su elección natural como sistemas de antenas de recolección de luz
que participan en procesos de transferencia de energía y electrones. En los últimos años, ha habido un gran interés
en el campo de las células solares orgánicas de heterounión masiva (BHJ) procesadas en disolución utilizando
derivados de porfirina como dadores y derivados de fulereno como aceptores, presentando resultados de PCE
del $9.06 \%$. En este trabajo se presenta la síntesis y propiedades de derivados de porfirinas A-D-A y el efecto de
la capa activa de tamaño nanométrico utilizando diferentes proporciones con PCBM como aceptor alcanzando
eficiencias superiores al $8 \%$.

Palabras claves: Energía solar, clorofila, heterounión masiva

\begin{abstract}
Tew generation of photovoltaics can provide an alternative and complementary approach for the exploitation 1 of solar energy; offering low manufacture cost, flexibility, light weight, and transparency. The most favorable solar cells are the organic solar cells (OSCs) because of their remarkable progress, hybrid dye-sensitized solar cells, and perovskite solar cells. Porphyrinsare synthetic analogues of natural chlorophylls are of particular interest, because they are a natural choice as light-harvesting antenna systems that are involved in energy and electron transfer processes. In recent years there has been a great interest on the field of solution-processed BHJ organic solar cells using porphyrin derivatives as donors and derivatives of fullerene as acceptors, which resulted in PCEs up to $9.06 \%$. This study presents the synthesis and properties of porphyrin A-D-A derivatives used as donor, and the effect of the nanometric size in the active layer with PCBM as acceptor, reaching efficiencies higher than $8 \%$.
\end{abstract}

Keywords: Solar energy, chlorophyll, massive heterojunction 